\title{
A State of the Art on Red Mud as a Substitutional Cementitious Material
}

\author{
Chava Venkatesh*, Madduru Sri Rama Chand, Ruben Nerella \\ Department of Civil Engineering, Vignan Foundation for Science, Technology\& Research, Guntur, Andhra Pradesh, India
}

Corresponding Author Email: chvenky288@gmail.com

https://doi.org/10.18280/acsm.430206

Received: 23 January 2019

Accepted: 6 April 2019

\section{Keywords:}

substitutional cementitious material,Red mud, bayer process, microstructure characterization, chloride ions diffusion, compressive strength

\begin{abstract}
Red mud is a highly alkaline solid waste produced from the alumina refinery plants. Every year more than 300 million tons of red mud is producing throughout world. Disposal of a large quantity of red mud is very expensive and it creates contamination of neighbor lands, air and water bodies. Using red mud as a sustainable cementitious material in concrete is highly appreciable, because concrete is a second largest using material after water. Moreover, reduce the negative effect on environment due to red mud disposal as well as cement industries. The present paper conducted a critical review on bayer process of red mud, physical and chemical properties of red mud. And also workability, mechanical, durability and microstructure characterization of red mud when used in concrete as sustainable cementitious material. In the red mud iron oxide and alumina oxide are presented abundantly. Red mud accelerates the heat of hydration in concrete and it leads to strength enhancement in early ages. Increases the quantity of red mud in concrete reduces the workability but increases the strength of concrete. However, the chemical composition of red mud and its particle size helps to improve the durability property of concrete. Red mud offers more capable to arrest the chloride ions and other ions diffusion into concrete. Red mud minimizes the micro cracks and voids present in concrete by its particles size as well as bonding nature with other materials up to certain dosage of red mud used in concrete.
\end{abstract}

\section{INTRODUCTION}

Concrete is a second highest using material after water in earth. It is a combination of cement, fine aggregate, coarse aggregate, and water [1]. According to the 2012- 2017 statistics. Every year approximately 4000 million metric tons of cement produced throughout the world, out of that India is producing more than 270 million metric tons, and it is the second highest contributor form worldwide. Carbon dioxide is a major atmospheric pollutant emission from cement production industries, because one ton of clinker produces one ton $\mathrm{CO}_{2}$ emission into the atmosphere [2]. To control the pollution due to cement production, some of the industrial byproducts like FA, GGBS, RHA, SF and others are used as secondary cementitious materials [3-9].

Red mud is a highly alkaline solid waste produced from the alumina refinery plants. Generally, red mud comes out from the bayer process or sintering process of alumina production. It is in from of slurry with high amount of sodium aluminates [10]. Every year, more than 300 million tons of red mud is producing from the alumina industries in worldwide. The disposal of large quantities of red mud is very difficult and it leads to land, air and water pollution [11]. Because it has high alkaline nature and it contains many hazardous substances like metals and radioactive elements [12-14]. In the alumina production, one ton of alumina produces 1-1.5 tonnes of red mud [15]. The bauxite ore and refining process can influence the amount of red mud comes as a wastage. Many studies are done to use red mud in several industrial products such as ceramic tiles, brick manufacturing, cement production, land reclamation and others [10-15]. Also, red mud used in the treatment of waste water and exhaust gas as an adsorbent [1520]. The adsorbents are used to extract the hazardous metals, both organic and inorganic substance in industries.

Considering the EPA report, after neutralization of red mud, it is considered as a non-hazardous material. In this study, red mud is tested to identify hazardous properties like ignitability, corrosivity, toxicity, and reactivity. All tested hazardous properties are within the limits and it is suggested to use red mud as a building material and also used as a raw material in metallurgical and glass production industries [21].

Chemical characterization of red mud varies from the one bauxite ore to another bauxite ore and also varies from refining process (sintering/bayer process) [22]. In sintering process, the presence of $2 \mathrm{CaO} . \mathrm{SiO}_{2}$ in red mud which helps to use directly as a building materials [23-26]. But in the Bayer process, the red mud is not attainable to use directly in building materials. Because, it contains less pozzolanic minerals due to presence of high-iron, high-aluminum boehmite and gibbsite bauxite [16][227]. Red mud has high alkaline nature and contains high aluminum oxide $\left(\mathrm{Al}_{2} \mathrm{O}_{3}\right)$ and iron oxide $\left(\mathrm{Fe}_{2} \mathrm{O}_{3}\right)$ which enhance the passivating layer on the reinforcement bar in the concrete against chloride ions attack and carbonation [28].

The study conducted a critical review on red mud bayer process, various disposal methods, its chemical properties also workability, durability, mechanical properties of concrete when red mud used as partial replacement to cement. 


\section{BAYER PROCESS OF RED MUD}

Karl Josef Bayer has invented the Bayer process in 1888 as shown in Figure 1. In this process, the concentrated sodium hydroxide solution used to digest the broken bauxite ores are heated up to a range of $150{ }^{\circ} \mathrm{C}$ to $230{ }^{\circ} \mathrm{C}$. Afterward, the major part of the aluminum oxide and sodium aluminate slurry are dissolved in the sodium hydroxide solution. Finally the slurry is filtered and the wastage from filters called as red mud. If the presence of $\mathrm{Al}_{2} \mathrm{O}_{3} / \mathrm{SiO}_{2}$ ratio is greater than 7 in the bauxite ore, then only the Bayer process can be suitable for refinery process. If $\mathrm{Al}_{2} \mathrm{O}_{3} / \mathrm{SiO}_{2}$ ratio is less than 7 , sintering process can be suitable for refining the bauxite ore. The following figure represents the alumina production process [10, 29-30].

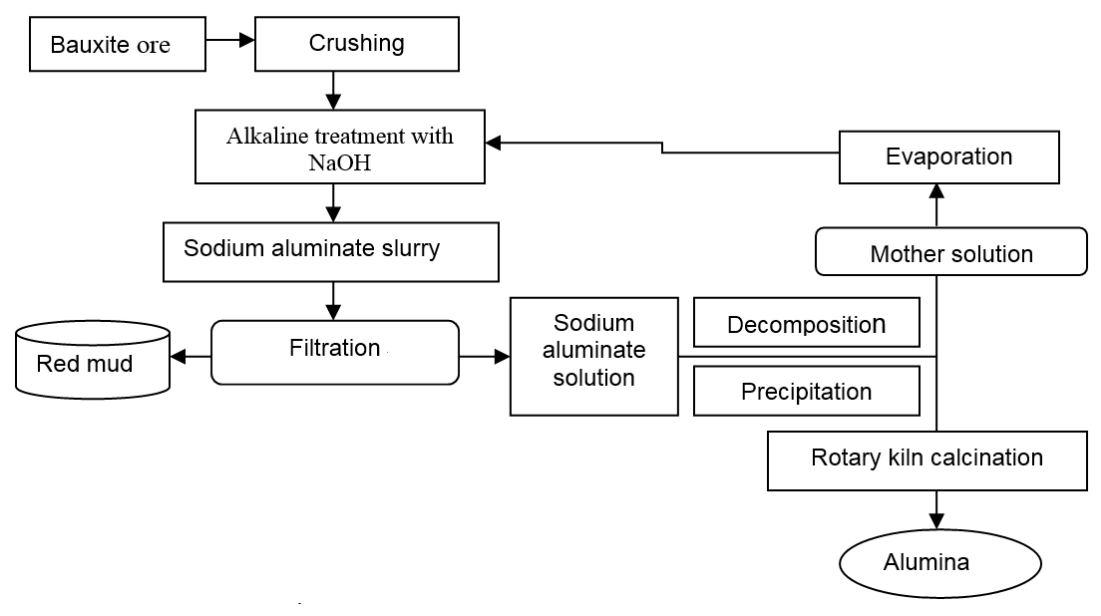

Figure 1. Bayer process [21]

\section{METHODS OF DISPOSAL}

\subsection{Closed cycle disposed system}

In this method red mud is stored or disposed in artificial ponds shown in Figure 2. But, the drawback of this method is in the monsoon season red muds is overflow from ponds and create a server problem to nearby lands, crops and water bodies etc [31-34].

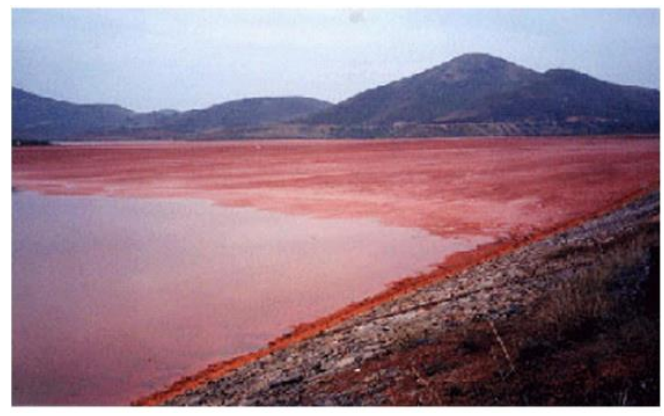

Figure 2. Pond disposal [14]

\subsection{Direct disposal method}

In this method red mud is directly disposed in the sea water through pipes shown in Figure 3. In this process acerbity of red mud is neutralized by the sea water and iron oxide released into the seawater, which helps to enhance the life system of the water living bodies (Corals, algae, and others) [35]. Another study reported that, the disposal of red mud into the seawater creates a major hazard to the water living bodies, because the presence of alumina and magnesium in red mud. Worldwide many types of seashore based alumina refinery plants countries like. Japan, Greece, and Australia are using this method [31-35].

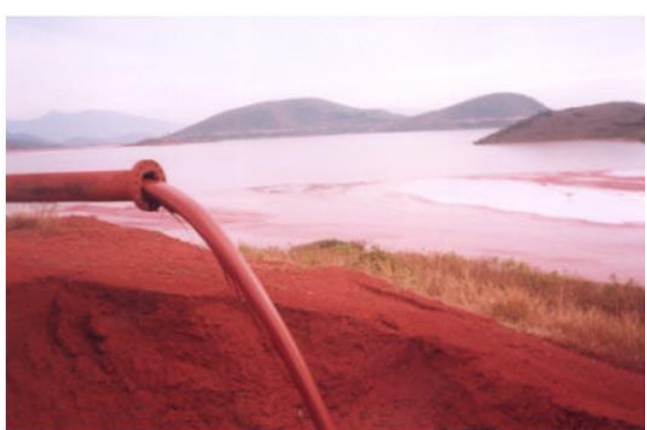

Figure 3. Direct Disposal [14]

\subsection{Dry disposal method}

It is an advanced method than others. In this method, the waterlogged slurry presence in the red mud is filtered several times so that water gets separated. Another reason for filtering of red mud is to take out the soda and minimizing alkalinity content from it. The dried red mud disposed on a pond side or open place like dumped or pyramid shape as shown in Figure 4. To restrain neighborhood places against pollution due to metallic dust present in the red mud, a regular water sprinkling is required [31-35].

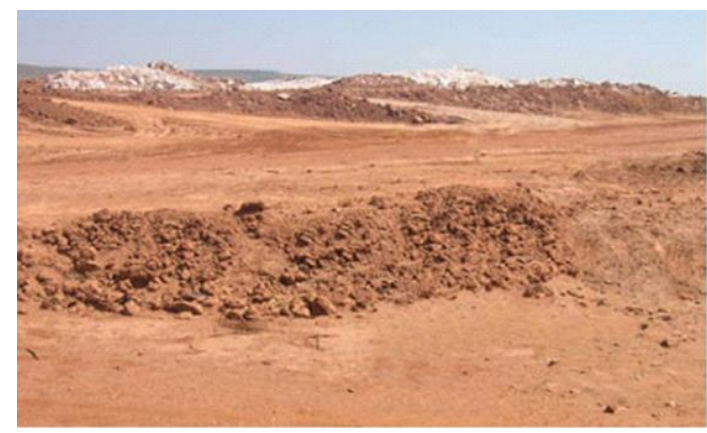

Figure 4. Dry Disposal [14] 


\section{CHEMICAL COMPOSITION OF RED MUD}

The chemical composition of red mud varies from the one bauxite ore to another bauxite ore and also varies from the refining process as shown in Figure 5. Based on the chemical analysis, the main chemical composition of red mud is alumina oxide $\left(\mathrm{Al}_{2} \mathrm{O}_{3}\right)$, iron oxide $\left(\mathrm{Fe}_{2} \mathrm{O}_{3}\right)$, silica oxide $\left(\mathrm{SiO}_{2}\right)$, titanium oxide $\left(\mathrm{TiO}_{2}\right)$, calcium oxide $(\mathrm{CaO})$, sodium oxide $\left(\mathrm{Na}_{2} \mathrm{O}\right)$ and some minor elements are also there like $\mathrm{Ba}, \mathrm{U}, \mathrm{Nb}, \mathrm{Hf}, \mathrm{Zr}, \mathrm{Cd}$, $\mathrm{V}, \mathrm{Cr}, \mathrm{Ni}, \mathrm{Mn}, \mathrm{Pb}, \mathrm{Th}, \mathrm{Zn}, \mathrm{Ga}, \mathrm{Mg}, \mathrm{Cu}$ and rare earths. In the case of the Bayer process alumina oxide and iron oxide are major constituents. But, in case of sintering process silica oxide and calcium oxide are major constituents. Red mud is formed from the following mineralogical composition of quartz, hematite, goethite, anatase, gibbsite, desilication product (DSP), boehmite, and calcite [35-37].

\section{RED MUD USED IN CEMENT PRODUCTION}

The present trend is utilization of residues from various industries are playing an important role in the safe and low cost of disposal of residue. To identify the proper exploitation of residue in different ways which cause no water and land pollutions. Any industrial waste contains $\mathrm{Cao}, \mathrm{Fe}_{2} \mathrm{O}_{3}, \mathrm{Al}_{2} \mathrm{O}_{3}$, and $\mathrm{SiO}_{2}$ can be used in cement production process or as a partial replacement to the cement $[26,39]$.

Red mud solids contain nearly $400 \mathrm{~g} / \mathrm{L}$ of water content, and this is the major disadvantage of red mud to use as raw material in the cement manufacturing process [40]. In this study, to drain off the water content from the red mud, Ferro alumina was used about $5 \%$ weight of the red mud. The combination of mixture minerals of limestone, red mud and sandstone are used in cement manufacturing process. Singh, Upadhayay, \& Prasad (1996) were studied Combination of Red mud; lime, bauxite, and gypsum are used to prepare rich cement. Proportions of these materials influenced the strength of the cement. In this study two types sample were prepared 1) bauxite, red mud and lime 2) gypsum, bauxite, lime, and red mud [41]. The second combination has shown greater strength than controlled cement. Another study was done by Snars \& Gilkes (2009), cement mixture prepared by the combination of gypsum, lime, red mud, bauxite and fly ash. This combination of cement mixtures has shown very less strength than controlled cement [42].

a. India Hindlco, b. Italy Eurallumina, c.Truckey Seydisehir, d.UK ALCAN, e. Greece,f. Franace Aluminium Pechiney, g. Canda ALCAN, h. Jamaica, i. Chin

j. Australia WAPL, k. Brazil Alunorte, 1. Germany AOSG, m. Spain ALcoa, n.USA RMC

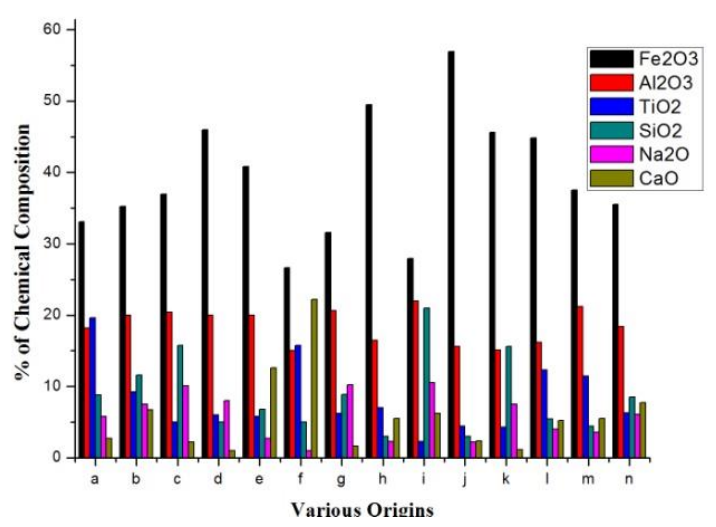

Figure 5. Chemical composition of red mud from various origins [38]

\section{RED MUD USED IN CONCRETE}

Nikbin, et al. (2018), Yao, et al. (2013), studied the combination of red mud and residue of coal industries are used in concrete as a partial replacement to cement $[39,43]$. The mechanical properties of red mud -coal residue based concrete shown greater than normal concrete. Manfroi, et al. (2014), prepared a cement paste sample with $15 \%$ of red mud by weight of cement and red mud heated at a temperature of 600 $900{ }^{\circ} \mathrm{C}$ before adding into cement [44]. The obtained results are satisfies the requirements and suggested to use red mud in concrete as a partial replacement to cement. Ribeiro, et al. (2011), concluded that cement mortar contains $25 \%$ and $50 \%$ of red mud decreases the compressive strength $18 \%$ and $36 \%$ at the age of 28 days with reference to controlled mortar. Red mud used as a partial replacement of $25 \%, 50 \%$ of cement, which shown $18 \%, 36 \%$ of lesser compressive strength of mortar with reference to the controlled sample after 28 days curing[45]. The enhancement of strength at early age is, because of rate hydration is more in the red mud based concrete at an early age [46-49]. Another study Tsakiridis et al., (2004), reported that reason for increasing strength at early ages is red mud is increased hydration process rapidly due to filling effect of red mud particle in the concrete[26]. Ashok kumra \& vikas singh (2015), conducted a study on red mud with various replacements in cement as shown in Figure 6[56].

In the case of self-compacting concrete, red mud used as a partial replacement to the cement about $2 \%$ of weight which enhanced the strength of concrete. But, red mud used greater than $2 \%$ the strength of concrete reduced compared to controlled concrete [50-51]. Another study K.K.Shetty et al. (2014) investigated on self-compacted concrete with a combination of $10 \%$ of iron ore and $2 \%$ of red mud in weight of cement the results showed that increased the flexural, tensile and compressive strengths [52]. Another study reported that greater compressive strength was obtained in selfcompacting concrete using fly ash $35 \%$ and red mud $15 \%$ as a replacement to cement in concrete. Liu \& Poon (2016), Studied on self-compacting concrete, red mud used as a partial replacement to fly ash. Increased the red mud content in cement increased the flexural and compressive strength of concrete but decreased the workability of concrete. The obtained results showed the compressive strength enhanced about 8-9 \% when red mud is replaced the fly ash about $30 \%$, $40 \%$ when compared to the conventional concrete. Also investigated on shrinkage behavior of concrete and concluded that because of internal curing effect in the red mud shown very low shrinkage of concrete [30].

In the case of geopolymer concrete, $\mathrm{Hu}$, et al. (2018) studied geopolymer concrete with a combination of FA, RM and $0 \%$ of $\mathrm{NaOH}$. Reported that $\mathrm{RM} / \mathrm{FA}$, curing duration, sand fillers are majorly influenced the mechanical properties of geopolymer concrete. Curing conditions increase the strength of concrete up to a certain level, and after completion of the curing process, it reaches the constant value. In this study, the compressive strength of geopolymer concrete is about 7-13 Mpa [53]. He, et al. (2013), prepared geopolymer with a combination of Rice husk ash, red mud, and $\mathrm{NaOH}$. This geopolymer $\mathrm{Si} / \mathrm{Al}$ ratio of 1.68 to 3.35 shown strength of concrete is $3.2-20.5 \mathrm{MPa}$. Many investigations are used a temperature about $50^{\circ} \mathrm{C}$ and $80^{\circ} \mathrm{C}$ in the curing process in red mud based geopolymer concrete [53-55]. 


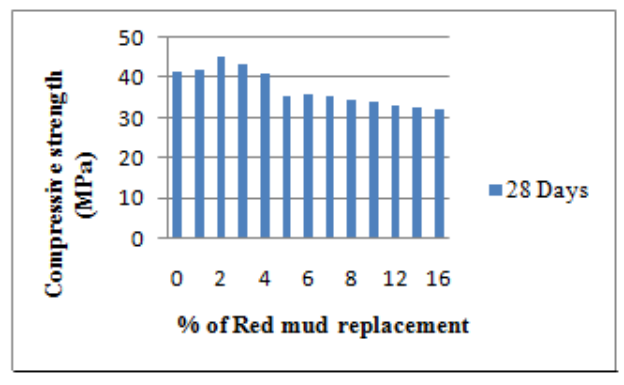

Figure 6. compressive strength of red mud based concrete [56]

\section{DURABILITY PROPERTY OF RED MUD BASED CONCRETE}

Ribeiro et al. (2012), Red mud offered more resistance against the chloride diffusion into concrete by its filling effects[57]. M.P.Deshmukh, et al. (2014), investigated on the durability of concrete when red mud is partially replaced in the crushed fine aggregates. This study reported that the content of red mud is increased then the chloride ions diffusion is decreased rapidly compared to normal concrete as shown in Figure 8. Increasing red mud content in the concrete reduces the carbonation depth, the reason for the reduction of carbonation depth is fineness of red mud is very higher than cement which helped to fill the all pores in the concrete [58]. However, the red mud based concrete can able to resist the corrosion potential Roshan Kumar et al. (2014). In the case of sulphate attack, the percentage of red mud increases the strength of concrete is reduced and also sulphate resistance capacity also reduced [59]. Cabeza, et al. (2003), reported that red mud is efficiently inhibiting the corrosion of steel bar embedded in the concrete contaminated with chlorides[60].

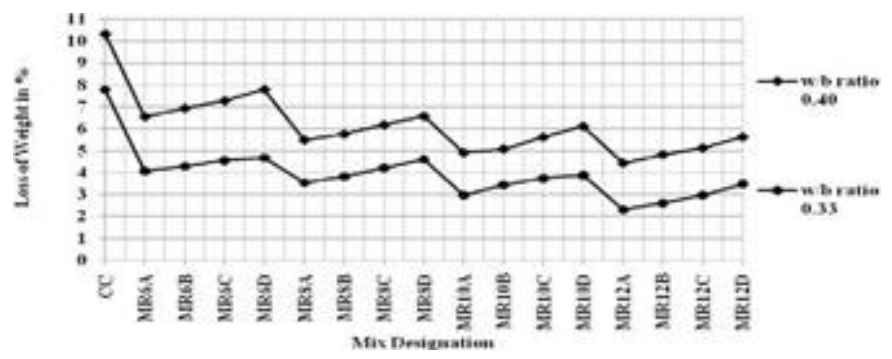

Figure 7. MK-RM Vs. loss of weight due to corrosion [61]

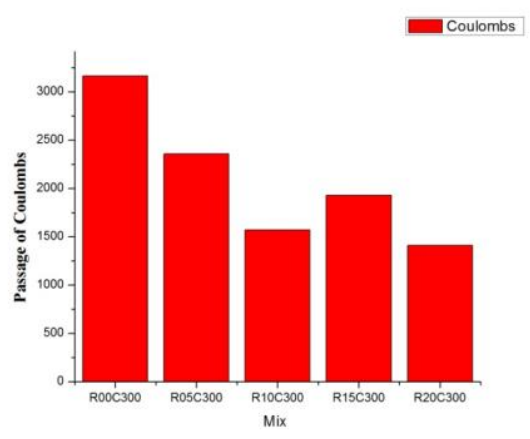

Figure 8. Passage of Coulombs Vs. \% of Red mud [58]

Rathan R.R., et al. (2013) Reported based on obtained results, the percentage of red mud increases with decreases the passage of current in the concrete compared with normal concrete. The content of red mud increases with decreases the weight loss of reinforcement bar compared to normal concrete. Red mud effectively forms a steel passivity layer on reinforcement bar, and it acts as a corrosion inhibitor[61]. R R Rathan, et al. (2012), Investigated on corrosion influence on concrete with a combination of red mud (RM) and Metakaolin (MK) with $0.33 \& 0.40 \mathrm{~W} / \mathrm{C}$. The study concluded that percentage of RM-MK is increased, weight loss of the concrete sample is decreased as shown in Figure 7. In case of $0.4 \mathrm{~W} / \mathrm{C}$ ratio, the percentage of weight loss is 4.91 of 50:50 (MK: RM) and 6.11 of $80: 20$ (MK: RM) in the $10 \%$ of MK$\mathrm{RM}$. These are lesser than the referenced concrete of 10.33. In case of $0.3 \mathrm{~W} / \mathrm{C}$ ratio, the percentage of weight loss is 2.98 of 50:50 (MK: RM) and 3.88 of 80:20 (MK: RM) in the $10 \%$ of MK-RM. These are lesser than the referenced concrete 7.7 [62].

\section{MICRO STRUCTURE CHARACTERIZATION OF RED MUD BASED CONCRETE}

Many researchers are studied about microstructure characterization of red mud and red mud based concretes and mortars [26, 49, 63-64]. In general, various techniques and tools (XRD, SEM, and EDS) are used for analyzing the microstructure of concrete. For identification of mineral phases and chemical composition of materials XRD analysis was used. For identification of interfacial transition zone and understanding the microstructure characterization SEM analysis was used. The area between the cement paste and aggregates is called as interfacial transition zone (ITZ). This ITZ is influenced by the mechanical properties of concrete such as strength, stiffness, and permeability. In case of brittle failure micro cracks are initially formed in the ITZ, then reached to the surface through high porosity and cement unhydrated cement in the concrete [49].
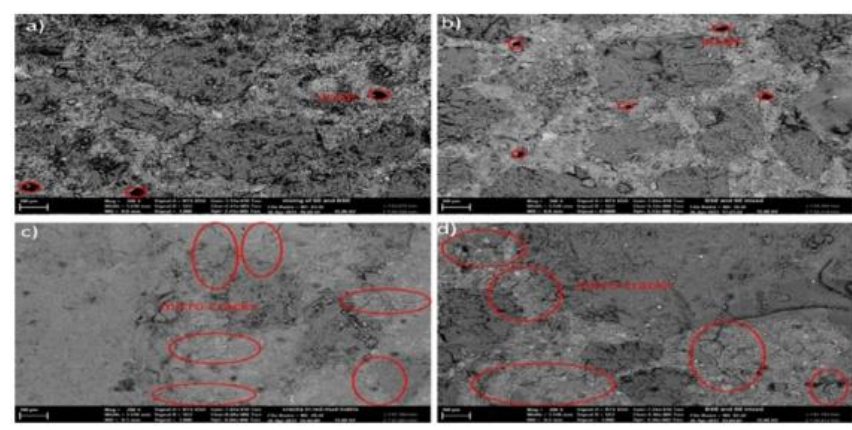

Figure 9. SEM. 5a) $0 \%$ of RM, 5b) $12.5 \%$ of RM, 5c) $25 \%$ of RM, 5d) $50 \%$ of RM [49]

In the case of SEM analysis, the surface of the concrete contained micro cracks and it is look likes flat uniform surface as shown in Figure 9a and 9b. But RMC 12.5 concrete contained a greater number of voids when compared to the RMC 0 . This is the reason for decreased compressive strength at the age of 56 days. RMC 25 represented poor bonding between the ingredients of concrete such as fly ash and aggregates and also represented more micro cracks and no voids compared with others shown in Fig 9c. RMC 50 contained many micro crakes and it is closely related with RMC 25 in the form of thickness and length of crack as shown in Figure 9d. The reason for the more water absorption of red 
mud based concrete is the micro cracks are presented like RMC 50, and RMC 25 leads to the porous nature of concrete [49].

In the case of XRD analysis, red mud based concrete majorly exhibited chemical composition is portlandite, mullite, calcite, quartz, katoite, hatrurite, anorthite, albite, etc [26, 49, 57] $\mathrm{Wu}$, Chuan-sheng et al. (2012). Increasing the content of red mud katoite, alibite and hatrurite are increased, but calcite and quartz are decreased compared to the controlled concrete as shown in Figure 10. But in case of controlled concrete exhibited chemical composition is a higher percentage of portlandite and quartz lesser percentage of albite and tricalcium silicate compared with red based concrete as shown in Figure 11

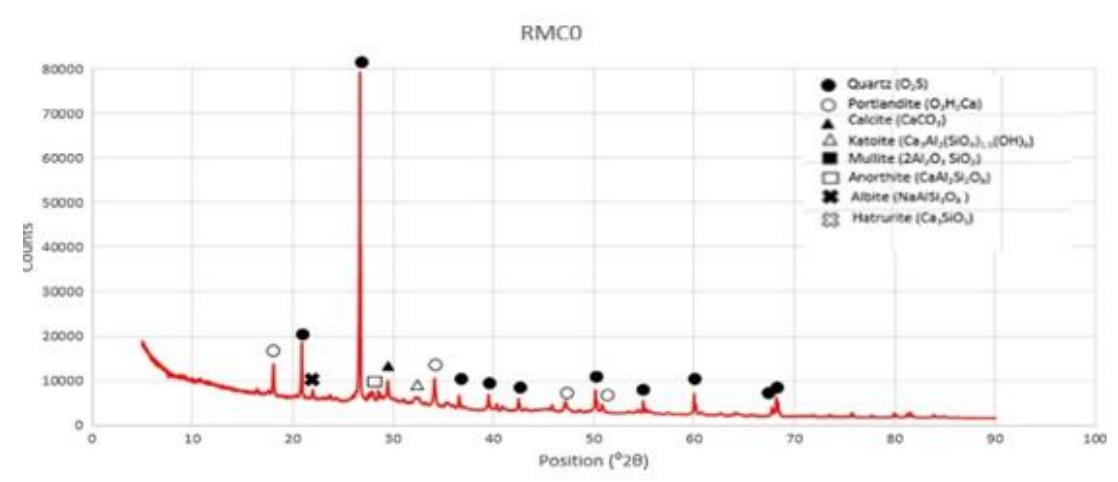

Figure 10. XRD for controlled concrete [49]

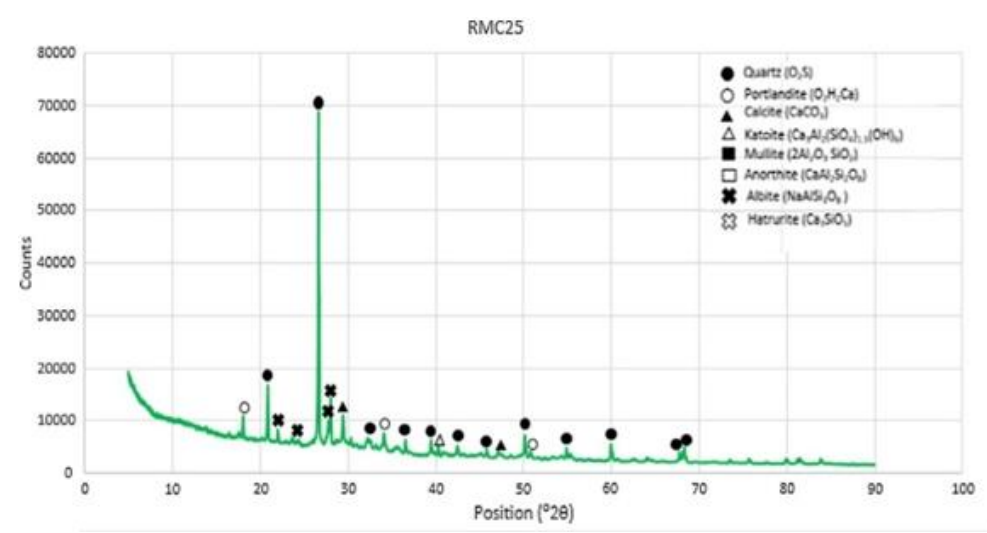

Figure 11. XRD for $25 \%$ of red mud replacement [49]

\section{CONCLUSIONS}

In the present study reviewed on red mud bayer process, disposal methods and utilization of red mud in cement and concrete industries, and also reviewed on mechanical, durability and microstructure characterization of red mud based mortar and concrete.

The chemical composition of red mud varies from the one bauxite ore to another bauxite ore and also varies from the refining process. In case of sintering process silica oxide and calcium oxide are major constituents. These are developing good pozzolanic properties in the concrete and suggested to use directly as a building material. But, in the Bayer process alumina oxide and iron oxide are major constituents, which have less pozzolanic nature. Red mud solids contain nearly $400 \mathrm{~g} / \mathrm{L}$ of water content, and this is the main drawback of red mud to use as raw material in the cement manufacturing process. Red mud based concrete enhance the strength at early ages because of rate hydration is more in the red mud based concrete at an early age. Reason for increasing strength at early ages of red mud is increased hydration process rapidly due to filling effect of red mud particle in the concrete. Increasing the percentage of red mud decreasing the strength of concrete and reducing the workability. Beyond the optimum dosage of red mud content in concrete leads to formation of microcracks. This reason for the more water absorption of red mud based concrete is the micro cracks are leads to the high porous nature of concrete. Red mud can be resisting the carbonation and chloride diffusion into concrete by its filling effects. Reduce the capability of sulfate resistance of concrete by adding more content of red mud. In the case of rebar corrosion, the content of red mud increases with decreases the weight loss of reinforcement bar compared to the bar in normal concrete. Red mud effectively forms a steel passivity layer on reinforcement bar, and it acts as a corrosion inhibitor.

\section{REFERENCES}

[1] Bouaissi, A., Li, L., Abdullah, M.M., Bui, Q. (2019). Mechanical properties and microstructure analysis of FA-GGBS-HMNS based geopolymer concrete. Construction and Building Materials, 210: 198-209. https://doi.org/10.1016/j.conbuildmat.2019.03.202

[2] Mikulčić, H., Klemeš, J.J., Vujanović, M., Urbaniec, K., Duić, N. (2016). Reducing greenhouse gasses emissions by fostering the deployment of alternative raw materials and energy sources in the cleaner cement manufacturing 
process. Journal of Cleaner Production, 136: 119-132. https://doi.org/10.1016/j.jclepro.2016.04.145

[3] Temuujin, J., Surenjav, E., Ruescher, C.H., Vahlbruch, J. (2019). Processing and uses of fly ash addressing radioactivity (critical review). Chemosphere, 216: 866882. https://doi.org/10.1016/j.chemosphere.2018.10.112

[4] Singhal, S., Tiwari, A., Kumar, A. (2018). Study the strength of concrete by using silica fume and GGBS with magnetized water. International Journal of Current Engineering and Technology, 8(5): 1318-1321. https://doi.org/10.14741/ijcet/v.8.5.15

[5] Makaratat, N., Rattanashotinunt, C., Jaturapitakkul, C. (2018). Low $\mathrm{CO}_{2}$ concrete made from calcium carbide residue, palm oil fuel ash, rice husk-bark ash, and recycled aggregates. In 2018 Third International Conference on Engineering Science and Innovative Technology (ESIT). IEEE, 1-12. https://doi.org/10.1109/ESIT.2018.8665036

[6] Hemalatha, T., Ramaswamy, A. (2017). A review on fly ash characteristics-Towards promoting high volume utilization in developing sustainable concrete. Journal of Cleaner Production, 147: 546-559. https://doi.org/10.1016/j.jclepro.2017.01.114

[7] Barbhuiya, S., Chow, P., Memon, S. (2015) Microstructure, hydration and nanomechanical properties of concrete containing metakaolin. Construction and Building Materials, 95: 696-702. https://doi.org/10.1016/j.conbuildmat.2015.07.101

[8] Malhotra, V.M. (1993). Fly ash, slag, silica fume, and rice husk ash in concrete: A review. Concrete International, 15(4): 23-28.

[9] Xiao, Y., Yang, H., Zhu, N., Zhang, Q., Zhang, Z. (2016). Design and research of double-pump fly ash conveying system. Advances in Modelling and Analysis C, 71: 7491.

[10] Khairul, M.A., Zanganeh, J., Moghtaderi, B. (2019). The composition, recycling and utilisation of Bayer red mud. Resources, Conservation and Recycling, 141: 483-498. https://doi.org/10.1016/j.resconrec.2018.11.006

[11] Alam, S., Das, S.K., Rao, B.H. (2019). Strength and durability characteristic of alkali activated GGBS stabilized red mud as geo-material. Construction and Building Materials, 211: 932-942. https://doi.org/10.1016/j.conbuildmat.2019.03.261

[12] Ortega, J.M., Cabeza, M., Tenza-Abril, A.J., RealHerraiz, T., Climent, M.Á., Sánchez, I. (2019). Effects of red mud addition in the microstructure, durability and mechanical performance of cement mortars. Applied Sciences, 9(5): 984. https://doi.org/10.3390/app9050984

[13] Qu, Y., Li, H., Wang, X., Tian, W., Shi, B., Yao, M., Zhang, Y. (2019). Bioleaching of major, rare earth, and radioactive elements from red mud by using indigenous chemoheterotrophic bacterium acetobacter $\mathrm{sp}$. Minerals, 9(2): 67. https://doi.org/10.3390/min9020067

[14] Samal, S., Ray, A.K., Bandopadhyay, A. (2013). Proposal for resources, utilization and processes of red mud in India - a review. International Journal of Mineral Processing, 118: 43-55. https://doi.org/10.1016/j.minpro.2012.11.001

[15] Liu, Z., Li, H. (2015). Metallurgical process for valuable elements recovery from red mud-A review. Hydrometallurgy, 155: 29-43. https://doi.org/10.1016/j.hydromet.2015.03.018
[16] Pokorski, M. (2019). Efficient management in the construction industry under the current market. World Scientific News, 126: 88-100.

[17] Venkatesh, C., Mohiddin, S.K., Ruben, N. (2019). Corrosion inhibitors behaviour on reinforced concretea review. In Sustainable Construction and Building Materials. Springer, Singapore, 25(12): 127-134. https://doi.org/10.1007/978-981-13-3317-0_11

[18] Metilda, D.L., Selvamony, C., Anandakumar, R., Seeni, A. (2015). Investigations on optimum possibility of replacing cement partially by redmud in concrete. Scientific Research and Essays, 10(4): 137-143. https://doi.org/10.5897/sre2015.6166

[19] Shetty, K.K., Nayak, G., Vijayan, V. (2014). Effect of red mud and iron ore tailings on the strength of selfcompacting concrete. European Scientific Journal, ESJ, $10(21)$. http://dx.doi.org/10.19044/esj.2014.v10n21p\%25p

[20] Shakir, A.A., Naganathan, S., Mustapha, K.N.B. (2013). Development of bricks from waste material: A review paper. Australian Journal of basic and applied sciences, 7(8): 812-818.

[21] Nenadovic, S., Mucsi, G., Kljajevic, L., Mirkovic, M., Nenadovic, M., Kristaly, F., Vukanac, I. (2017). Physicochemical, mineralogical and radiological properties of red mud samples as secondary raw materials. Nuclear Technology and Radiation Protection, 32(3): 261-266. https://doi.org/10.2298/ntrp1703261n

[22] Topličić-Ćurčić, G., Mitic, V., Grdić, D., Ristić, N., Grdić, Z. (2017). Environmental aspects of red mud and its utilization as a component of building materials. In Proceedings of the IV Advanced Ceramics and Applications Conference, Atlantis Press, Paris, pp. 447474. https://doi.org/10.2991/978-94-6239-213-7_31

[23] Sutar, H., Mishra, S.C., Sahoo, S.K., Maharana, H.S. (2014). Progress of red mud utilization: An overview. American Chemical Science Journal, 4: 255-279.

[24] Liu, Y., Lin, C., Wu, Y. (2007). Characterization of red mud derived from a combined Bayer Process and bauxite calcination method. Journal of Hazardous Materials, 146(1-2): https://doi.org/10.1016/j.jhazmat.2006.12.015 255-261.

[25] Yang, J.K., Chen, F., Xiao, B., Liu, W. (2006). Engineering application of basic level materials of red mud high level pavement. China Municipal Engineering, 5: 7-9.

[26] Tsakiridis, P.E., Agatzini-Leonardou, S., Oustadakis, P. (2004). Red mud addition in the raw meal for the production of Portland cement clinker. Journal of Hazardous Materials, 116(1-2): 103-110. https://doi.org/10.1016/j.jhazmat.2004.08.002

[27] Liu, X., Zhang, N. (2011). Utilization of red mud in cement production: A review. Waste Management \& Research, 29(10): 1053-1063. https://doi.org/10.1177/0734242X11407653

[28] Megat-Yussof, P.S., Afolabi, L.O., Arogundade, A.I., Muriana, R.A. (2018). Effect of bauxite residue on the corrosion resistance of an intumescent paint coated steel plate. In AIP Conference Proceedings, 2035(1): 080005. AIP Publishing. https://doi.org/10.1063/1.5075604

[29] Xie, L., Zhang, T., Lv, G., Yang, J., Wang, Y. (2018). The effect of $\mathrm{NaOH}$ on the direct calcificationcarbonation method for processing of Bayer process red 
mud. Green Processing and Synthesis, 7(6): 546-551. https://doi.org/10.1515/gps-2017-0070.

[30] Liu, R.X., Poon, C.S. (2016). Utilization of red mud derived from bauxite in self-compacting concrete. Journal of cleaner production, 112: 384-391. https://doi.org/10.1016/j.jclepro.2015.09.049

[31] Patel, S., Pal, B.K. (2015). Current status of an industrial waste: Red mud an overview. Ijltemas, 4(8): 1-16.

[32] Liu, Z., Li, H. (2015). Metallurgical process for valuable elements recovery from red mud-A review. Hydrometallurgy, 155: 29-43. https://doi.org/10.1016/j.hydromet.2015.03.018

[33] Ujaczki, É., Klebercz, O., Feigl, V., Molnár, M., Magyar, Á., Uzinger, N., Gruiz, K. (2015). Environmental toxicity assessment of the spilled Ajka red mud in soil microcosms for its potential utilisation as soil ameliorant. Periodica Polytechnica Chemical Engineering, 59(4): 253-261. https://doi.org/10.3311/ppch.7839

[34] Dentoni, V., Grosso, B., Massacci, G. (2014). Environmental sustainability of the alumina industry in Western Europe. Sustainability, 6(12): 9477-9493. https://doi.org/10.3390/su6129477

[35] Abdel-Raheem, M., Santana, L.M., Cordava, M.A., Martínez, B.O. (2017). Uses of red mud as a construction material. AEI 2017. https://doi.org/10.1061/9780784480502.032

[36] Xue, S., Zhu, F., Kong, X., Wu, C., Huang, L., Huang, N., Hartley, W. (2016). A review of the characterization and revegetation of bauxite residues (Red mud). Environmental Science and Pollution Research, 23(2): 1120-1132. https://doi.org/10.1007/s11356-015-4558-8

[37] Zhu, X., Li, W., Guan, X. (2015). An active dealkalization of red mud with roasting and water leaching. Journal of hazardous materials, 286: 85-91. https://doi.org/10.1016/j.jhazmat.2014.12.048

[38] Liu, X., Zhang, N. (2011). Utilization of red mud in cement production: A review. Waste Management \& Research, 29(10): 1053-1063. https://doi.org/10.1177/0734242x11407653

[39] Nikbin, I.M., Aliaghazadeh, M., Charkhtab, S., Fathollahpour, A. (2018). Environmental impacts and mechanical properties of lightweight concrete containing bauxite residue (red mud). Journal of cleaner production, 172: 2683-2694 https://doi.org/10.1016/j.jclepro.2017.11.143

[40] Vangelatos, I., Angelopoulos, G.N., Boufounos, D. (2009). Utilization of ferroalumina as raw material in the production of ordinary portland cement. Journal of Hazardous Materials, 168(1): 473-478. https://doi.org/10.1016/j.jhazmat.2009.02.049

[41] Singh, M., Upadhayay, S.N., Prasad, P.M. (1996). Preparation of special cements from red mud. Waste Management, 16(8): https://doi.org/10.1016/s0956-053x (97)00004-4

[42] Snars, K., Gilkes, R.J. (2009). Evaluation of bauxite residues (red muds) of different origins for environmental applications. Applied Clay Science, 46(1): 13-20. https://doi.org/10.1016/j.clay.2009.06.014

[43] Yao, Y., Li, Y., Liu, X., Jiang, S., Feng, C., Rafanan, E. (2013). Characterization on a cementitious material composed of red mud and coal industry byproducts. Construction and Building Materials, 47: 496-501. https://doi.org/10.1016/j.conbuildmat.2013.05.030
[44] Manfroi, E.P., Cheriaf, M., Rocha, J.C. (2014). Microstructure, mineralogy and environmental evaluation of cementitious composites produced with red mud waste. Construction and Building Materials, 67: 2936. https://doi.org/10.1016/j.conbuildmat.2013.10.031

[45] Ribeiro, D.V., Labrincha, J.A., Morelli, M.R. (2011). Potential use of natural red mud as pozzolan for Portland cement. Materials Research, 14(1): 60-66. https://doi.org/10.1590/s1516-14392011005000001

[46] Pontikes, Y., Angelopoulos, G.N. (2013). Bauxite residue in cement and cementitious applications: current status and a possible way forward. Resources, Conservation and Recycling, 73: 53-63. https://doi.org/10.1016/j.resconrec.2013.01.005

[47] Ramesh, M., Karthic, K.S., Karthikeyan, T., Kumaravel, A. (2014). Construction materials from industrial wastes - a review of current practices. International journal of Environmental Research and Development, 4(4): $317-324$

[48] Ribeiro, D.V., Silva, A.S., Labrincha, J.A., Morelli, M.R. (2013). Rheological properties and hydration behavior of portland cement mortars containing calcined red mud. Canadian Journal of Civil Engineering, 40(6): 557-566. https://doi.org/10.1139/cjce-2012-0230

[49] Tang, W.C., Wang, Z., Liu, Y., Cui, H.Z. (2018). Influence of red mud on fresh and hardened properties of self-compacting concrete. Construction and Building Materials, 178: 288-300. https://doi.org/10.1016/j.conbuildmat.2018.05.171

[50] Kushwaha, M., Akhtar, S., Rajput, S. (2013). Development of the self compacting concrete by industrial waste (red mud). Development, 3(4): 539-542.

[51] Shetty, K.K., Nayak, G., Shetty, R. (2014). Self compacting concrete using red mud and used foundry sand. International Journal of Research in Engineering and Technology, 3(3): 708-711. https://doi.org/10.15623/ijret.2014.0315133

[52] Hu, W., Nie, Q., Huang, B., Shu, X., He, Q. (2018). Mechanical and microstructural characterization of geopolymers derived from red mud and fly ashes. Journal of Cleaner Production, 186: 799-806. https://doi.org/10.1016/j.jclepro.2018.03.086

[53] He, J., Jie, Y., Zhang, J., Yu, Y., Zhang, G. (2013). Synthesis and characterization of red mud and rice husk ash-based geopolymer composites. Cement and Concrete Composites, 37: 108-118. https://doi.org/10.1016/j.cemconcomp.2012.11.010

[54] Petermann, J.C., Saeed, A., Hammons, M.I. (2010). Alkali-activated geopolymers: A literature review. Applied Research Associates Inc Panama City Fl. https://doi.org/10.21236/ada559113

[55] Zhang, G., He, J., Gambrell, R.P. (2010). Synthesis, characterization, and mechanical properties of red mudbased geopolymers. Transportation Research Record: Journal of the Transportation Research Board, 2167(1): 1-9. https://doi.org/10.3141/2167-01

[56] Kumar Yadav, A., Singh, V. (2015). Effect of selfcompacting concrete by red mud. International Journal for Scientific Research \& Development, 3(1): 308-310.

[57] Ribeiro, D.V., Labrincha, J.A., Morelli, M.R. (2012). Effect of the addition of red mud on the corrosion parameters of reinforced concrete. Cement and Concrete Research, $\quad 42(1)$ : https://doi.org/10.1016/j.cemconres.2011.09.002 
[58] Deshmukh, M.P., Sarode, D.D., Chaube A. (2014). Effect of partial replacement of crushed fine aggregates with an industrial waste (red mud) on chloride penetration of concrete. International Journal of Current Engineering and Technology, 6(4): 4026-4029.

[59] Kumar, R. (2014). Study of effect of red mud on the properties of concrete. Diss. National Institute of Technology, Kurukshetra.

[60] Ribeiro, D.V. (2011). Influência da Temperatura de Calcinação nas Propriedades Cimentícias do Resíduo de Bauxita. Relatório Científico Final de Pós-Doutorado, apresentado à Fundação de Amparo à Pesquisa do Estado de São Paulo (FAPESP). São Carlos, SP, pp. 78.

[61] Raj Rajendran, R., Perumal Pillaib, E.B., Santhakumai, A.R. (2013). Effective utilization of red mud bauxite waste as a re-placement of cement in concrete for environmental conservation. Ecology, Environment and Conservation, 19(1): 247-255.

[62] Raj, R.R., Pillai, E.P., Santhakumar, A.R. (2012). Strength and corrosion properties of concrete incorporating metakaolin and redmud. European Journal of Scientific Research, 91(4): 569-579.

[63] Zhang, N., Sun, H., Liu, X., Zhang, J. (2009). Early-age characteristics of red mud-coal gangue cementitious material. Journal of Hazardous Materials, 167(1-3): 927932. https://doi.org/10.1016/j.jhazmat.2009.01.086

[64] Wu, C.S., Liu, D.Y. (2012). Mineral phase and physical properties of red mud calcined at different temperatures. Journal of Nanomaterials, https://doi.org/10.1155/2012/628592 